\title{
Marketing Strategies for the Developing Tourism and Its Impact on the Poverty Alleviation in Sindh
}

\author{
Muhammad Suhail Nazar \\ Department of Management Sciences \\ Islamic University Bahawalpur, Pakistan \\ E-mail: Suhail_nazar@yahoo.com \\ Professor Dr. Abdul Latif \\ Chairman Department of Management Sciences \\ Islamia University Bahawalpur, Pakistan \\ E-mail: drabdullatif@hotmail.com \\ Dr. Najma Noor Phulpoto \\ Assistant Professor, Deptt: of Sociology \\ SALU-Khairpur Mirs, Pakistan \\ Faiz Muhammad Shaikh \\ Assistant Professor \\ SZABAC-Dokri-Larkana, Pakistan \\ E-mail: faianmy2000@hotmail.com
}

Received: November 8, 2010

Accepted: December 7, 2010

doi:10.5539/ijms.v3n2p134

\begin{abstract}
This research investigates the marketing opportunities by developing tourism in Pakistan. Data were collected from 2000 households from four districts i.e. Shikarpur, Larkana, Sukkur, and Jacobabad of upper Sindh by using the simple random technique; a structural questionnaire was design as an instrument tool for measuring the poverty. It was revealed that better tourism development strategies create employment opportunities for the local people and reduce poverty in the selected sample districts. It was further revealed that Government should initiated the some suitable strategies for developing tourism in Pakistan so helps in reducing poverty in selected areas.
\end{abstract}

Keywords: Strategies, Poverty, Tourism, Pakistan

\section{Introduction}

Pakistan is unique! Situated in the heart of the South Asian sub-continent, it is a country with its own history and cultural heritage, fascinating in its own right. Pakistan was the site for one of the world's earliest human settlements, the great prehistoric Indus Valley Civilization, the crucible of ancient empires, religions and cultures. The land of Pakistan ranges from lofty mountains in the north, the Karakoram and the Himalayas, through dissected plateaus to the rich alluvial plains of the Punjab. Then follows desolate barrenness of Baluchistan and the hot, dry deserts of Sindh blending into miles and miles of golden beaches of Makran coast. Come and Explore the Treasures of Pakistan with us. A visitor to Pakistan is more than a tourist - to us he is an honored guest. Change is the basic need of life and with out this change no human being can ever think of surviving. Tours and trips have got a great value because they bring about change in life apart from this they have also got a 
great educative value. Tourists are the people who bring people of different cultures together. Tourism spreads love, mutual understanding and knowledge.

If we compare Pakistan with other, nations as far as tourism is concerned than we find out that very few countries offer such variety, as does Pakistan. The reason being that Pakistan has got a very diverse culture, having natural endowments as well as historic treasure, which I am sure that is, possessed by very few nations. Switzerland is known and famous as the most beautiful country because it has got a massive natural endowment, which is considered to be better than any other place in the world. Believe me that if you ever visit Pakistan's northern areas than you will find no difference between Pakistan and Switzerland.

Pakistan has got a separate tourism department for the spread of tourism in Pakistan namely PTDC that is Pakistan tourism development corporation. PTDC provides suitable literature and information to foreign tourists as well as the locals. The basic motive of this corporation is to spread tourism in Pakistan. Pakistan tourism Development Corporation has got it's offices in Karachi, Lahore, Islamabad and Abbottabad.

A large number of tourists visit Pakistan all year round. Pakistan's historical places and natural beauty attract the foreigners who know the art of making the best out of life. Pakistan is endowed with a rich and varied flora and fauna. High Himalayas, Karakoram and the Hindukush ranges with their alpine meadows and permanent snow line, coniferous forests down the sub-mountain scrub, the vast Indus plain merging into the great desert, the coast line and wetlands, all offer a remarkably rich variety of vegetation and associated wildlife including avifauna, both endemic and migratory. Ten of 18 mammalian orders are represented in Pakistan with species ranging from the world's smallest surviving mammals, the Mediterranean Pigmy Shrew, to the largest mammal ever known; the blue whale.

Poverty has many faces it is a never ending problem confronting all governments and policy makers. This is true regardless of weather the country belongs to higher or lower stage of development. Depending on the country concerned, the incidence of poverty differs in degree only and not so much in form. In fact, the attributes of poverty are many. The historical experience suggests that some of these attributes are very conspicuous at some stage of development while others are at another stage of development. The expenditures on education, health and housing tantamount to investment in human capital. The greater provision of these services helps enhance the productivity of labour i.e. the income while the limited access to these retards the productivity. This the expenditure on these provision is redistributive in nature since these services by the way of maintaining or expanding productivity through good health as well as skills contribute to the higher potential of the poor households to earn more thereby improving their position based on income classification. The access to education expands the potential for human capital thereby enabling one to qualify for better paid jobs. This is how the expenditure on education and health for poor households helps in the redistribution of income in their favor. It has been empirically substantiated that even at the macro level the educated parents give relatively more priorities to the health and education in Pakistan.( poverty with Many Fact Ataul Huq Pramanik). Based on the Federal Bureau of Statistics' PSLM data, the Centre for Poverty Reduction and Social Policy Development (CPRSPD), Planning and Development Division estimated a sharp decline in the headcount poverty ratio for 2007-08. However, these findings appear to contradict other assessments conducted subsequently, and which better reflect global and domestic price developments after June 2008. These subsequent assessments point towards a strong likelihood of a sharp increase in the poverty incidence in Pakistan as a result of unprecedented food inflation and transmission of international energy prices to domestic consumers. The Report of a UN Inter Agency Assessment Mission fielded during June-July 2008 found that food security in Pakistan in 2007-08 had significantly worsened as a result of food price hike. The total number of households falling into this category was estimated to be seven million households or about 45 million people in 2008. In relative terms, the increase is more pronounced in rural areas, where food expenditure rose by 10 percent and total expenditure by 4 percent. In absolute terms the increase has been higher in urban areas. The survey further indicates that more than 40 percent of households reported no change in income in 2008 since last year. Forty five percent of the population working as employees witnessed decrease in their real wages. The Report shows an increase in the share of severely food insecure population, from 23 percent in 2005-06 to 28 percent in 2008. The main findings indicate that the high food prices are undermining poverty reduction gains, as food expenditures comprise a large share of the poor's total expenditures and food price hike has severely eroded poor household purchasing power. The assessment shows that the share of households that cannot meet medical expenditure increased from six percent to thirty percent in 2008. Similarly, there is a serious risk of massive school dropout and thus loss of the gains in primary school enrolment achieved in past years. The poorest households need to spend 70 percent or more of their income on food and their ability to meet most essential expenditures for health and education is severely compromised. In addition, the diminished purchasing power has severely impaired capacity of poor households 
to seek health care, and children education, particularly for girls. This situation has further aggravated by falling nutrition levels, particularly for already malnourished children (Economic Survey of Pakistan 2008-09). The dynamic concept of poverty being considered as a process has also implication for the types of vulnerabilities confronting poor man. The poor regardless of their origins are in the constant threats of personal insecurity and unthought-of for crisis natural or man made. While the former results from the poor socio political and economic factors surrounding them, the latter from the unpredictable events beyond their control.

Tourism Development: Sindh is the rich in historical places in Pakistan, Moen-Jo-daro civilization and Jhirk hill near in Dadu District, Keejhar lake and Mansher lake these are the places where we can develop the tourism sector attract local as well as foreigners to visit those places.

\section{Literature Review}

Kakwani (1993) explored the relation between economic growth and poverty for Cote d' Ivoire from 1980-85. The study used the methodology of Kakwani and Subbarao (1990) to measure separately the impact of changes in average income and income inequality on poverty. The methodology was applied to the data taken from the 1985 Living Standards Survey in Cote d' Ivories. Poverty was found to be highly sensitive to economic growth. In fact, poverty in Cote d' Ivoire was found to decrease faster than the economic growth rate provided the growth process did not lead to an increase in income inequality. However, poverty measures were found to be considerably more elastic for changes in inequality. The numerical results for Cote d' Ivoire suggested that the smaller the poverty threshold, the greater the relative sensitivity of poverty was for changes in income inequality than for changes in the mean income. Thus, the ultra poor were considerably more affected by the changes in income inequality than by changes in mean income. The analysis also provided a link between the growth rates in various sectors of the economy and the total poverty. Using the poverty Elasticities and projected per capital growth rates, it was estimated that total poverty in Cote d' Ivoire would have increased at an annual rate of 3.63 percent during the 1986-90 period. The effect of changes in intersect oral inequality was computed to be equivalent to an increase in poverty by 1.95 percent. Ravallion and Datt (1994) endeavored to throw some empirical analysis.

\section{Data Collection Methodology}

Data were collected from 2000 households from four districts i.e. Shikarpur, Larkana, Sukkur, and Jacobabad of upper Sindh by using the simple random technique; a structural questionnaire was design as an instrument tool for measuring the poverty.

\section{Results and Discussions}

\subsection{Access to Education}

It appears from the result from our survey (Table-1) that the level of literacy among the household heads is higher in Lahore and Karachi and lower in case of Khuzdar Balochistan and average in Sukkur and Larkana.

\subsection{Access to Shelter}

The access to a safe and secure shelter is very vital in maintaining the productivity of poor households. The lack of this makes this vulnerable to natural disasters and uncertainties thereby reduction the earning potential of poor families. This truly depicts the perception of the poor people they were not knowing the poverty in real sense. The vulnerability of the poor household becomes evident from a very significant percentage of households without any legal right in all surveyed districts. The percentage is varies from the district to district.

The squttering on Government land is rather more conspicuous than that on the private land (Table-2). This is because the risk of being forcefully evident from Government owned land is relatively much less compared with land of under private ownership.

\subsection{Access to Health}

Like the access to safe and secure shelter, to safe drinking water is also used $\mathrm{s}$ an indicator of vulnerability to contagious diseases. The use of pipe water or tab water appears to be more favor of poor performers. The poor households from two better performing districts seems to be more exposed to drinking water from dug-well and river compared with two poor performing districts shows in Table-3. However time and budgetary constraints did not permit us to investigate how many of those are exposed to safe water i.e dug well and river do suffer from gastro intestinal including many other water-borne diseases like Cholera and diarrhea.

The demographic and social factors help us to find out the poverty position in various districts. It explain a large part of the poverty caused by the lower income level of the households. The income and expenditure pattern of the households as can be transpired through the sources from which incomes are generated together with the 
spending habits of poor families can also explain why the poor fail to come out the vicious circle without any big push from the outside forces to break that circle.

\subsection{Economic factors}

It is no doubt that the economic factors determining the sources of earnings and the unique spending pattern associated with the nature of the economic activities play a most vital role in explaining low level of income causing poverty. Usually the poor with less education and other assets, more mouth to feed, traditional life style and families values are risk averse. This mean those who cross certain age are rigid in terms of not trying out any new opportunities open to them until and unless they are fully convinced about the outcomes of the new ventures. Because they live in the same environment of poor achievement and fatalistic attitude they are also slow to adopt any changes. The empirical evidence also suggests that the incidence of poverty is very much sensitive to the magnitude as well as method of estimating poverty income line. Based on the detailed monthly expenditure per head is Rs. 10000 to Rs.15000. In Jacobabad Districts. District the poverty is much higher than other districts.

The main purpose of this study is to examine how the multi-furious factors contribute to perpetuation of poverty among some households although some other households despite being in a similar environment are able to come out of that circle. In the table -4 as has been discussed that the incidence of poverty including poor and hard core poor is much higher for two districts i.e Shikarpur and Jacobabad where economic condition and poverty rate is quiet high compare with Sukkur and Larkana. It is argued that in both district Shikarpur and Jacobabad the law and order situation is too bad and most of the business people migrate to Sukkur and Karachi.

The main findings of Table-4 seems to suggest that on average of the household income generated from the agriculture and most of the farmers are facing lot of problems regarding availability of water and inputs. By the criterion of derived demand the households from two districts Sukkur and Larkana engaged in productive activities to earn more compare with the Shikarpur and Jacobabad.

According to the results from occupational status the unemployment rate in the District Jacobabad is quiet high compare to all other districts. Nearly 99 percent of women in Jacobabad district are house wife. The percentage of factory workers in District Sukkur is relatively higher than the other districts.

\section{Conclusion}

The current research highlights the sustainable development through tourism development in Pakistan. The empirical evidence also suggests that the incidence of poverty is very much sensitive to the magnitude as well as method of estimating poverty income line. Based on the detailed monthly expenditure per head is Rs. 10000 to Rs.15000. In Jacobabad Districts District the poverty is much higher than other districts. Tourism development in these areas creates employment opportunities for the local people. Tourism can reduce poverty in the above districts.

\section{References}

Anderson, P. M., \& Levine, P. B. (1999). Child Care and Mother's Employment Decisions. Working Paper for National Bureau of Economic Research. [Online] Available: http://www.nber.org/papers/w7058.

Averett, S. L., Peter, H. E., \& Waldman, D. M. (1997). Tax Credits, Labor Supply and Child Care. The Review of Economics and Statistics, 79(1), 125-136.

Baum II, C. L. (2002). A Dynamic Analysis of the Effect of Child Care Costs on the Work Decisions of Low-income Mothers with Infants. Demography, 39 (1), 139-164.

Berger, M. C., \& Black, D. A. (1991). Child Care Subsidies, Quality of Care, and the Labor Supply of Low Income, Single Mothers. The Review of Economics and Statistics,70, 635-641.

Blau, D., \& Robins, P. (1988). Child-care Costs and Family Labor Supply. The Review of Economics and Statistics, 70 (3), 374-381.

Bormann, M. K., Quarm, D., \& Gideonse, S. (1984). Women in the workplace: Effects on families. Norwood, New Jersey: Ablex Publishing Corporation.

Connelly, R. (1992). The Effect of Child Care Costs on Married Women's Labor Force Participation. The Review of Economics and Statistics, 74(1), 83-90.

Doiron, D \& Kalb, G. (2005). Demands for Child Care and Household Labor Supply in Australia. The Economic Record, 81(254), 215-236.

Han, W. J., \& Waldfogel, J. (2001). Child Care Costs and Women's Employment: A Comparison of Single and 
Married Mothers with Pre-School-Aged Children. Social Science Quarterly, 82(3), 552-568.

Heckman, J. (1974). Effects of Child Care Programs on Women's Work Effort. Journal of Political Economy, 82, 136-163.

Hofferth, S. L., \& Wissoker, D. A. (1991). Price and Quality in Child Care Choice. Journal of Human Resources, 27(1), 70-111.

Kaufman, E.B. (1994). The economics of labor markets. 4th Edition. Georgia State Universities: The Dryden Press.

Kimmel, J \& Powell, L. M. (2006). Nonstandard Work and Child Care Choices of Married Mothers. Eastern Economic Journal, 32 (3), 397-419.

Kimmel, J. (1998). Child Care Costs As a Barrier to Employment for Single and Married Mothers. The Review of Economics and Statistics, 80(2), 287-299.

Leibowitz, A., Klerman, J. A., \& Waite, L. J. (1992). Employment of New Mothers and Child Care Choice: Differences by Children's Age. Journal of Human Resources, 27(1), 112-133.

Leibowitz, A., Waite, L. J., \& Wittsberger, C. (1988). Child care for Preschoolers: Differences by Child's Age. Demography, 205-220.

Lokshin, M., \& Fong, M. (2006). Women's labor Force Participation and Child Care in Romania. Journal of Development Studies, 42 (1), 90-109.

Michalopoulos, C., Robins, P., \& Garfinkel, I. (1992). A Structural Model of Labor Supply and Child Care Demand. Journal of Human Resources, 27, 166-203.

Oishi, A. S. (2001). The Effect of Childcare Costs on Mothers' Labor Force Participation. Paper for the Distribution of Income Project 1999-2001, 51-65.

Powell, L. M. (1998). Part-time versus Full-time Work and Child Care Costs: Evidence for Married Mothers. Applied Economics, 30(4), 503-511.

Ribar, D. (1992). Child Care and the Labor Supply of Married Women. Journal of Human Resources, 27(1), 134-165.

Robins, P. K., \& Spiegelman, R. G. (1978). An Econometric Model of the Demand for Child Care. Economic Inquiry, 16, 83-94.

Stolzenberg, R. M., \& Waite, L. J. (1988). Local Labor Market, Children and Labor Force Participation of Wives. Demography, 21(2), 157-168.

Table 1. Distribution of Household Heads Based on the Education Level-House Hold Heads General Level of education

\begin{tabular}{|l|l|l|l|l|l|l|l|l|l|}
\hline & 0 & 1 & 2 & 3 & 4 & 5 & 10 & 11 & Total \\
\hline Larkana & 110 & 56 & 40 & 33 & 30 & 30 & 25 & 20 & 344 \\
\hline Shikarpur & 150 & 50 & 40 & 30 & 25 & 25 & 20 & 20 & 360 \\
\hline Sukkur & 100 & 90 & 50 & 40 & 30 & 25 & 25 & 25 & 385 \\
\hline Jacobabad & 250 & 30 & 25 & 20 & 15 & 15 & 15 & 15 & 385 \\
\hline
\end{tabular}

Table 2. Distribution of Household Heads By the ownership status of Homestead Land

\begin{tabular}{|l|l|l|l|l|l|l|l|}
\hline & Own House & In hired & $\begin{array}{l}\text { Squatters } \\
\text { Govt-Land }\end{array}$ & $\begin{array}{l}\text { Squatters } \\
\text { Private-Land }\end{array}$ & Rented & $\begin{array}{l}\text { Mortgaged } \\
\text { And others }\end{array}$ & Total \\
\hline Larkana & 97 & 1 & 40 & 14 & 19 & 3 & 174 \\
\hline Shikarpur & 223 & 0 & 33 & 23 & 10 & 0 & 287 \\
\hline Sukkur & 92 & 1 & 59 & 39 & 41 & 3 & 235 \\
\hline Jacobabad & 57 & 1 & 29 & 3 & 4 & 0 & 94 \\
\hline
\end{tabular}


Table 3. Distribution of Household Heads Based on the Access to Drinking Water

\begin{tabular}{|l|l|l|l|l|l|}
\hline & Shikarpur & Sukkur & Larkana & Jacobabad & Total \\
\hline Drinking pipe water & 80 & 50 & 70 & 20 & 220 \\
\hline Dug well & 250 & 200 & 300 & 200 & 950 \\
\hline River & 10 & 60 & 20 & 20 & 110 \\
\hline Pond & 0 & 0 & 0 & 0 & 0 \\
\hline Private Tube-well & 10 & 0 & 0 & 0 & 10 \\
\hline
\end{tabular}

Table 4. Distribution of Household Heads Based Per capita Monthly Income in Pak-Rupees

\begin{tabular}{|l|l|l|l|l|l|l|l|l|l|}
\hline & Rs. 500 & Rs. 600 & Rs. 700 & Rs. 800 & Rs. 1000 & 1200 & 1400 & 1500 & Total \\
\hline Larkana & 12 & 30 & 50 & 60 & 80 & 90 & 100 & 110 & 432 \\
\hline Shikarpur & 10 & 40 & 50 & 55 & 65 & 70 & 75 & 85 & 450 \\
\hline Sukkur & 5 & 30 & 55 & 60 & 65 & 75 & 80 & 100 & 470 \\
\hline Jacobabad & 15 & 20 & 30 & 40 & 50 & 60 & 80 & 90 & 375 \\
\hline
\end{tabular}

Table 5. Distribution of Household Heads Based on Occupational Status (\%)

\begin{tabular}{|l|l|l|l|l|l|l|l|}
\hline & Farming & $\begin{array}{l}\text { Factory } \\
\text { Worker }\end{array}$ & $\begin{array}{l}\text { House } \\
\text { Wife }\end{array}$ & $\begin{array}{l}\text { Small } \\
\text { Business }\end{array}$ & Unemployed & Govt Jobs & Private Jobs \\
\hline Larkana & 50 & 33 & 95 & 55 & 70 & 15 & 15 \\
\hline Shikarpur & 55 & 30 & 97 & 45 & 65 & 20 & 15 \\
\hline Sukkur & 36 & 40 & 90 & 35 & 45 & 30 & 25 \\
\hline Jacobabad & 80 & 10 & 99 & 70 & 60 & 20 & 20 \\
\hline & & & & & & 100 & 100 \\
\hline
\end{tabular}

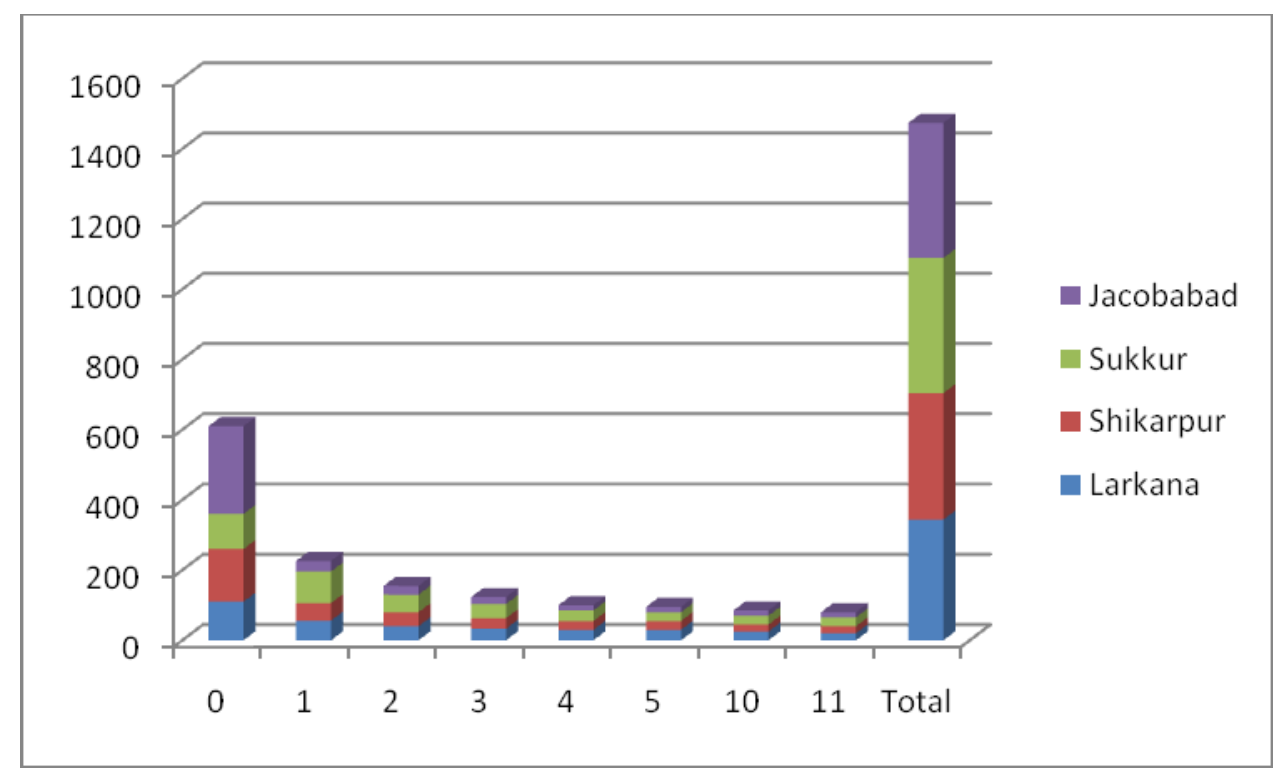

Figure 1. Distribution of Household Heads Based on the Education Level House Hold Heads General Level of education 


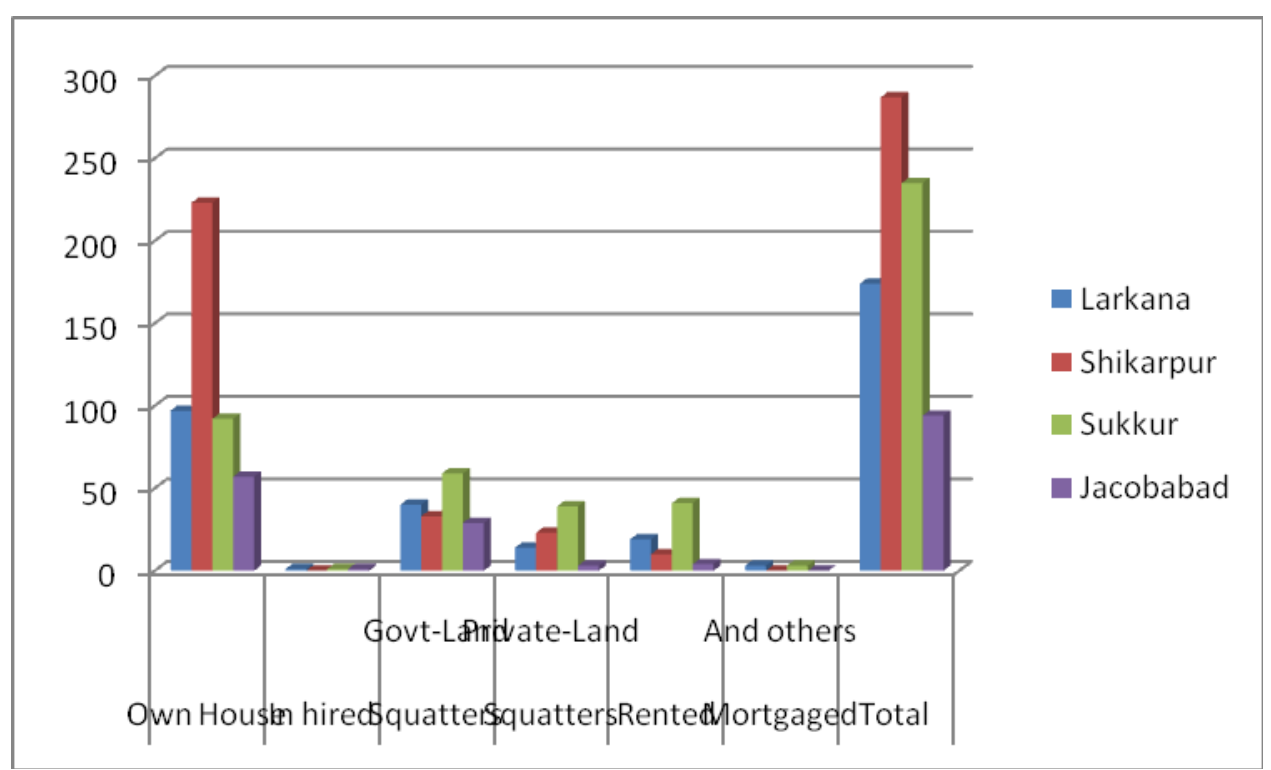

Figure 2. Distribution of Household Heads By the ownership status of Homestead Land

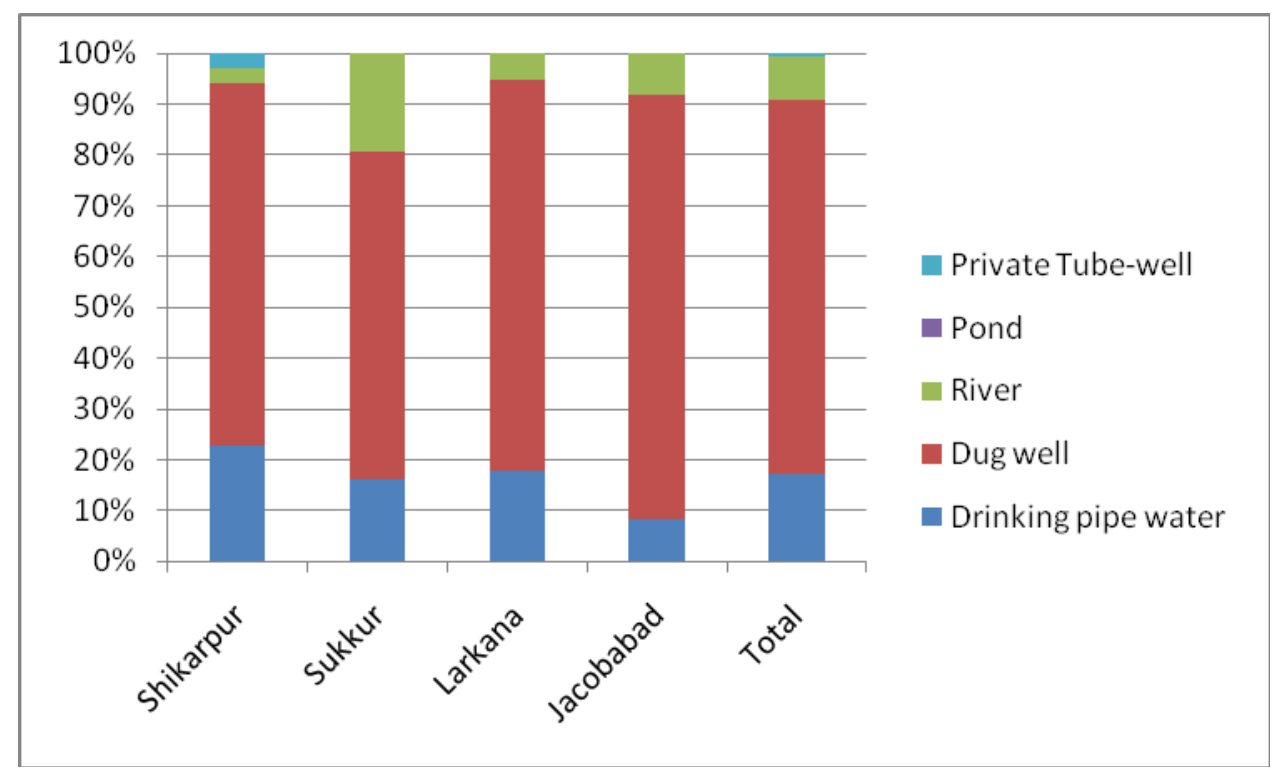

Figure 3. Distribution of Household Heads Based on the Access to Drinking Water 


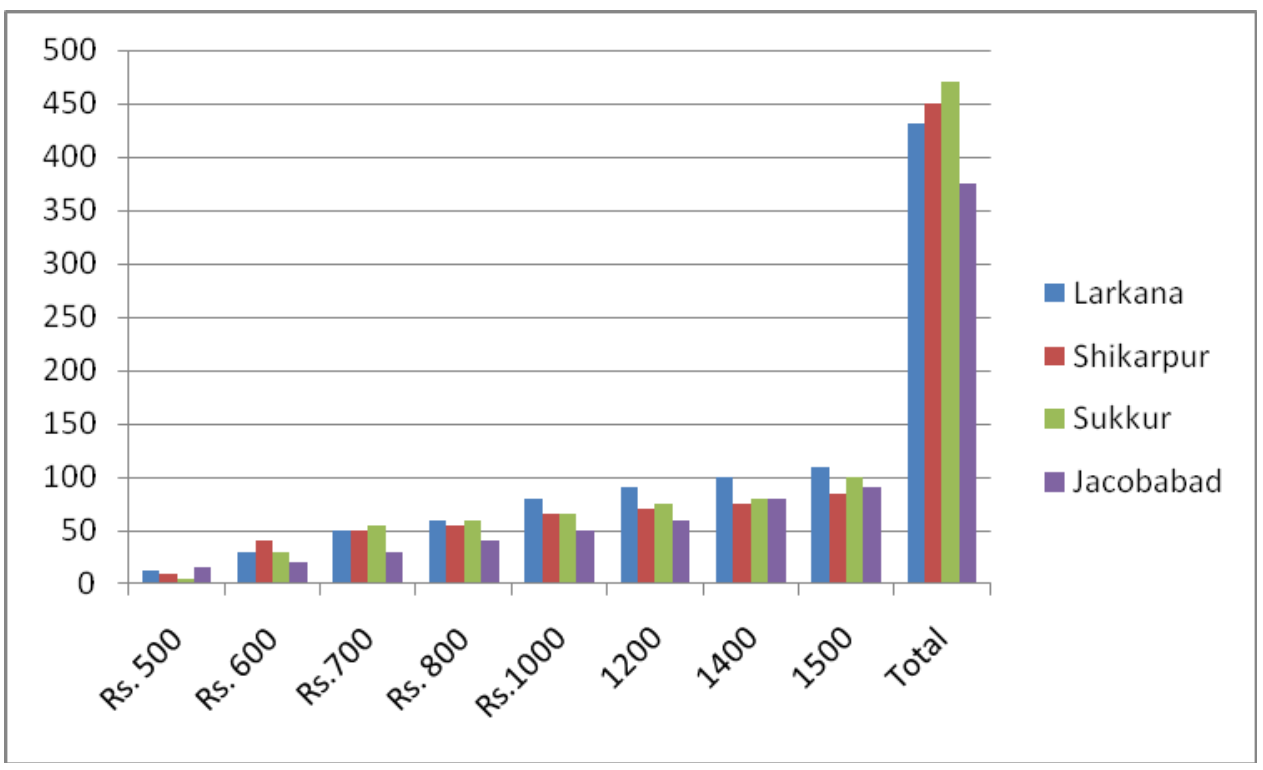

Figure 4. Distribution of Household Heads Based Per capita Monthly Income in Pak-Rupees

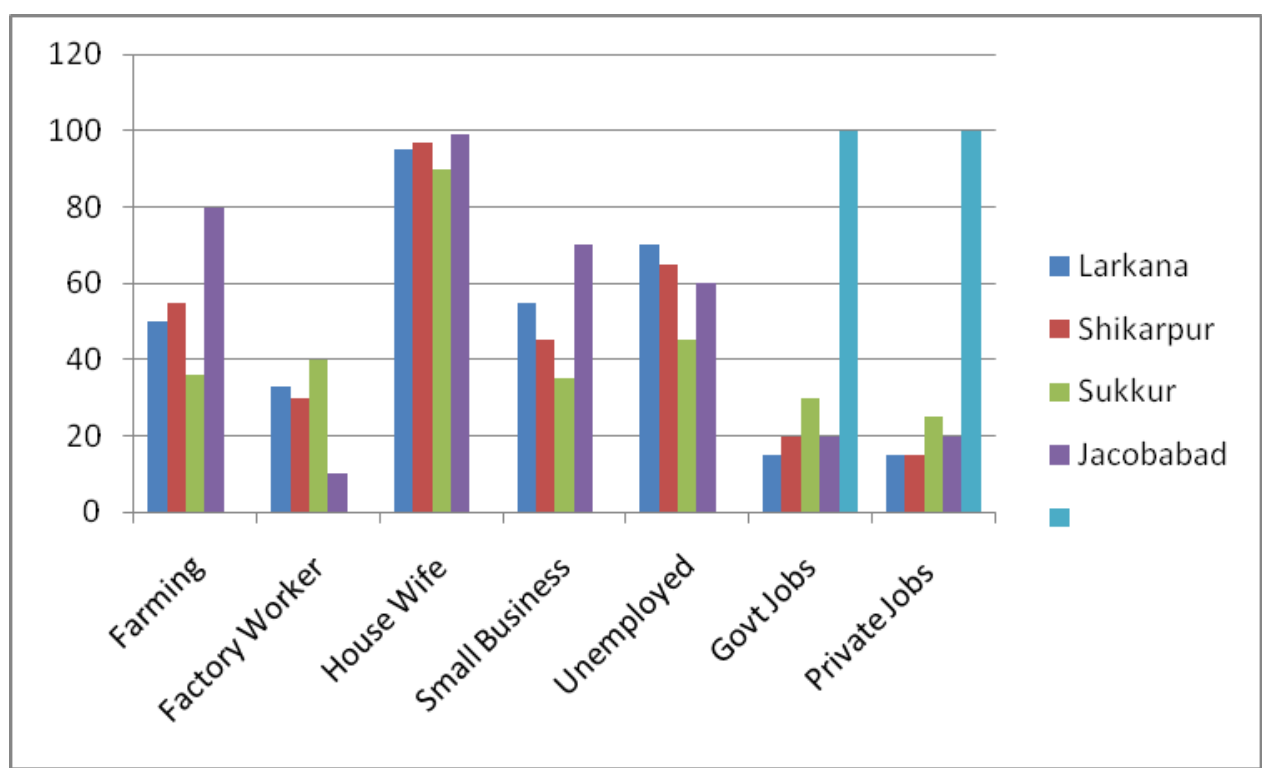

Figure 5. Distribution of Household Heads Based on Occupational Status (\%) 